\title{
Integrated Detection of Pathogens and Host Biomarkers for Wounds
}

Military Interdepartmental Purchase Request: MIPR1EO89M1115

\author{
Crystal Jaing \\ Lawrence Livermore National Laboratory
}

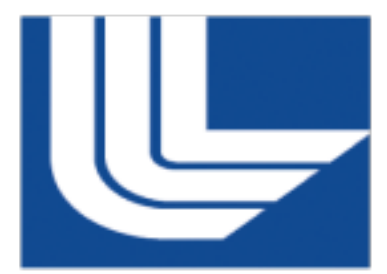

This document was prepared as an account of work sponsored by an agency of the United States government. Neither the United States government nor Lawrence Livermore National Security, LLC, nor any of their employees makes any warranty, expressed or implied, or assumes any legal liability or responsibility for the accuracy, completeness, or usefulness of any information, apparatus, product, or process disclosed, or represents that its use would not infringe privately owned rights. Reference herein to any specific commercial product, process, or service by trade name, trademark, manufacturer, or otherwise does not necessarily constitute or imply its endorsement, recommendation, or favoring by the United States government or Lawrence Livermore National Security, LLC. The views and opinions of authors expressed herein do not necessarily state or reflect those of the United States government or Lawrence Livermore National Security, LLC, and shall not be used for advertising or product endorsement purposes.

This work performed under the auspices of the U.S. Department of Energy by Lawrence Livermore National Laboratory under Contract DE-AC52-07NA27344. 
Military Interdepartmental Purchase Request: MIPR1EO89M1115

TITLE: Integrated Detection of Pathogens and Host Biomarkers for Wounds

PRINCIPAL INVESTIGATOR: Crystal Jaing

CONTRACTING ORGANIZATION: Lawrence Livermore National Laboratory

REPORT DATE: March 10, 2013

TYPE OF REPORT: Annual

PREPARED FOR: U.S. Army Medical Research and Materiel Command

Fort Detrick, Maryland 21702-5012

DISTRIBUTION STATEMENT: Approved for Public Release;

Distribution Unlimited

The views, opinions and/or findings contained in this report are those of the author(s) and should not be construed as an official Department of the Army position, policy or decision unless so designated by other documentation. 


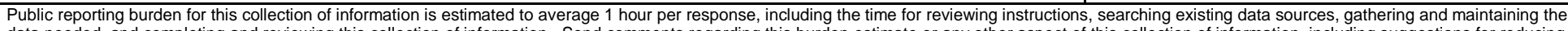

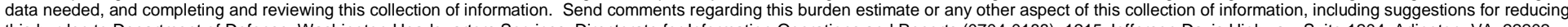

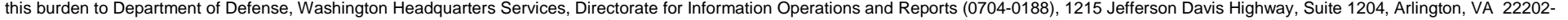

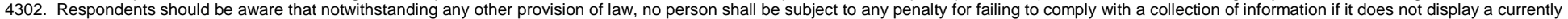
valid OMB control number. PLEASE DO NOT RETURN YOUR FORM TO THE ABOVE ADDRESS.

\begin{tabular}{l|l|l}
\hline 1. REPORT DATE & 2. REPORT TYPE & 3. DATES COVERED
\end{tabular}

21-03-2013 Annual

4. TITLE AND SUBTITLE Annual April 1, 2011 - March 21, 2012

Integrated Detection of Pathogens and Host Biomarkers for Wounds (1) MIPR1EO89M1115

5b. GRANT NUMBER

DM102734

5c. PROGRAM ELEMENT NUMBER

\section{AUTHOR(S)}

Crystal Jaing, Nicholas Be, Brett Chromy, Paul Luciw

5d. PROJECT NUMBER

E-Mail: jaing2@IInl.gov, be1@IInl.gov, brett.chromy@ucdmc.ucdavis.edu, paluciw@ucdavis.edu

\section{PERFORMING ORGANIZATION NAME(S) AND ADDRESS(ES)}

Lawrence Livermore National Laboratory

7000 East Avenue, Livermore, CA 94550

\section{5e. TASK NUMBER}

5f. WORK UNIT NUMBER

8. PERFORMING ORGANIZATION REPORT NUMBER

University of California, Davis

One Shields Avenue Davis, CA 94518

9. SPONSORING I MONITORING AGENCY NAME(S) AND ADDRESS(ES)

U.S. Army Medical Research and Materiel Command

Fort Detrick, Maryland 21702-5012

10. SPONSOR/MONITOR'S ACRONYM(S)

11. SPONSOR/MONITOR'S REPORT NUMBER(S)

\section{DISTRIBUTION I AVAILABILITY STATEMENT}

Approved for Public Release; Distribution Unlimited

\section{SUPPLEMENTARY NOTES}

\section{ABSTRACT}

The increasing incidence and complications arising from combat wounds has necessitated a reassessment of methods for effective treatment. Infection, excessive inflammation, and incidence of drug-resistant organisms all contribute toward negative outcomes for afflicted individuals. The organisms and host processes involved in wound progression, however, are not well understood. We therefore set out, using our unique technical resources, to construct a profile of combat wounds. We employed the Lawrence Livermore Microbial Detection Array and next-generation sequencing to identify all microorganisms present in wound samples, building complete profiles of wound infection. These methods allowed for comprehensive assessment of the wound bioburden, revealing pathogens that could not be detected by standard microbiology. Further, we developed and applied proteomics technology and identified host biomarkers associated with wound resolution. In combination with our pathogen data, these biomarker discovery efforts will provide a profile that will assist in clinical outcome classification and will provide vital insight for treatment of these complex cases.

\section{SUBJECT TERMS}

Wound infection, biomarker, nosocomial pathogen, host-pathogen interaction

\begin{tabular}{|c|c|c|c|c|c|}
\hline \multicolumn{3}{|c|}{ 16. SECURITY CLASSIFICATION OF: } & \multirow{2}{*}{$\begin{array}{l}\text { 17. LIMITATION } \\
\text { OF ABSTRACT } \\
\text { UU }\end{array}$} & \multirow{2}{*}{$\begin{array}{l}\text { 18. NUMBER } \\
\text { OF PAGES } \\
14\end{array}$} & \multirow{2}{*}{$\begin{array}{l}\text { 19a. NAME OF RESPONSIBLE PERSON } \\
\text { USAMRMC } \\
\text { 19b. TELEPHONE NUMBER (include area } \\
\text { code) }\end{array}$} \\
\hline $\begin{array}{r}\text { a. REPORT } \\
U\end{array}$ & $\begin{array}{c}\text { b. ABSTRACT } \\
U\end{array}$ & $\begin{array}{c}\text { c. THIS PAGE } \\
\text { U }\end{array}$ & & & \\
\hline
\end{tabular}


Introduction.

Body: Research methods and results.................................... 5

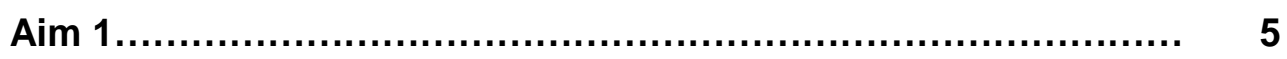

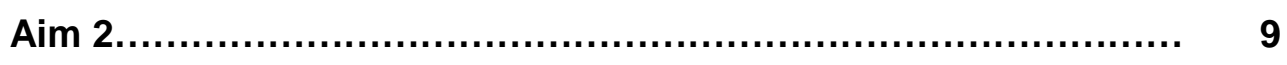

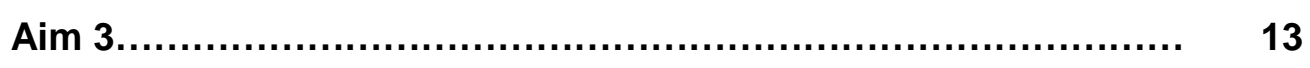

Key Research Accomplishments.......................................... 14

Reportable Outcomes.................................................. 14

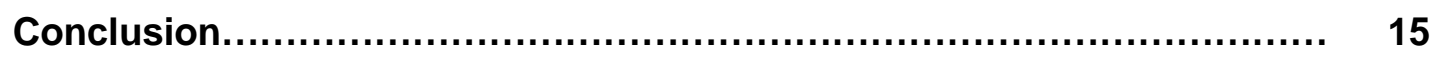

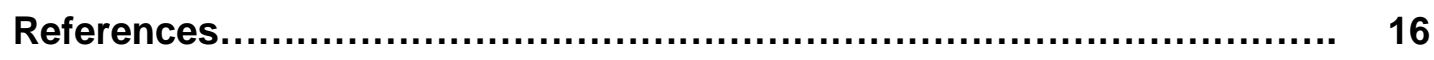

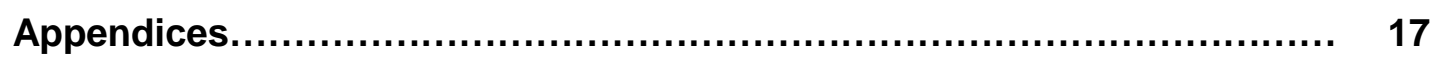




\section{INTRODUCTION}

Modern combat environments present many unique and difficult challenges to the evolution of medical treatment for the warfighter. Improvised explosive devices, increasing number and severity of injuries per casualty, longer transport times, and higher died-of-wound rates have necessitated a reassessment of our approach to wound treatment.

One of the most important determining factors in wound resolution is the degree to which infection is observed, and whether the infection manifests in an acute or chronic manner. Previous studies of wound infection have focused on a relatively small subset of well-characterized pathogens such as Staphylococcus aureus and Pseudomonas aeruginosa [1-3]. Recent studies, however, indicate that analysis of wound infection via standard microbiological techniques likely overestimates the importance of readily-cultured species in chronic wounds [4]. It is becoming clear that the community of microorganisms inhabiting the human body, collectively known as the human microbiome, represent tremendous breadth and microbial diversity, and that a much broader range of organisms likely plays a role in wound response. Many of these organisms may be difficult or impossible to culture using standard protocols, and their importance in infection may be previously unrecognized. A comprehensive approach is therefore needed in order to completely assess the role of microbial communities in wound pathology.

Also highly relevant to treatment of combat wounds are host response mechanisms. Biomarkers such as inflammatory cytokines and chemokines could provide informative indications of likely outcome and appropriate timing of wound closure [5]. Past studies examining the chemical immune response in serum and wound effluent demonstrated that such biomarkers are capable of predicting healing and identifying instances where immune dysregulation results in healing failure [6]. This process also involves the regulation of matrix remodeling metalloproteinases, profiles of which have predicted outcome for traumatic war wounds [7].

Construction of a comprehensive panel of host response biomarkers, in combination with a microbial profile of corresponding wounds, would aid tremendously in clinical decision-making. We therefore assembled a collaborative and experienced team, combining the extensive clinical wound research expertise and the unique wound sample collection from the Naval Medical Research Center (NMRC), the advanced and proven bioinformatics and pathogen detection expertise from the Lawrence Livermore National Laboratory (LLNL), and the proteomic and biomarker research expertise from the University of California, Davis to conduct a comprehensive characterization of microorganisms and host proteins associated with negative or positive wound outcomes. A Cooperative Research and Development Agreement (CRADA) was established between the three institutions to perform this study. In year 2, the CRADA was expanded to include Walter Reed Army Institute of Research as a collaborator to gain additional expertise in wound infection and microbial characterization.

We elected to analyze wound samples using the Lawrence Livermore Microbial Detection Array (LLMDA) [8], which is a highly cost-effective detection and discovery platform for the identification of a very broad range of microbes. For host factors, we optimized a 2-D difference gel electrophoresis (2D DIGE) system to identify protein biomarkers. Our unique approach of characterizing both host and pathogen profiles in wound healing will reveal unique aspects of these essential interactions and will improve the ultimate outcome and quality of life of wound victims. 


\section{BODY: RESEARCH METHODS AND RESULTS}

\section{Aim 1: Detection of microbial pathogens in wounds (LLNL)}

\section{Methods}

Nucleic acid processing from wound samples. Tissue and effluent samples were collected from 131 debridement procedures representing 61 wounds in 44 combat-injured service member patients evacuated to the National Capital Area from Iraq and Afghanistan. We extracted nucleic acid from tissue and effluent using the DNA mini kit and Qiaamp cador pathogen mini kit (Qiagen). Briefly, we disrupted and homogenized tissues and cells via bead-beating and high-speed vortexing in the presence of $0.1 \mathrm{~mm}$ silica/zirconia beads, performed further cellular digestion by incubation with proteinase $\mathrm{K}$, and collected and purified nucleic acid using the manufacturer's provided centrifugation columns.

Microarray sample preparation and hybridization. We labeled resultant DNA with Cy3 fluorescent dye (Roche) using random primers and isothermal amplification with klenow polymerase. Labeled DNA was purified via isopropanol precipitation and resuspended in water for microarray hybridization. The recently updated LLMDA (version 5) contains probes designed to detect genomic DNA from all currently sequenced microbial pathogens. All data derived during year two of this project employed the 12-plex version of this updated array. DNA samples were prepared for hybridization using the Nimblegen Hybridization Kit LS (Roche). Ten $\mu \mathrm{g}$ labeled DNA was hybridized to each array, followed by incubation for $45-60$ hours at $42^{\circ} \mathrm{C}$. Arrays were washed using the Nimblegen Wash Buffer Kit (Roche) and scanned at $2 \mu \mathrm{m}$ resolution using the Nimblegen MS200 microarray scanner.

Microarray data analysis. We analyzed data using an automated composite likelihood maximization method developed at LLNL [8]. We required that positive probes exhibit a signal intensity in the $99^{\text {th }}$ percentile above random negative control probes. Additionally, eight probes were required to be detected from a given sequence in order for that target to qualify as a positive target, and these detected probes were required to comprise at least $20 \%$ of total expected probes for the given target.

Next-generation sequencing. We selected six wound samples for a pilot next-generation sequencing analysis. Sequencing was performed at the California Institute for Quantitative Biosciences, Vincent J. Coates Genomics Sequencing Laboratory (Berkeley, CA). DNA samples were processed on the Illumina Hiseq 2000 platform using 100 bp paired-end reads, multiplexing three samples in each flow cell lane. We employed a whole genome sequencing approach in order to capture information from bacterial, plasmid, viral, and fungal sequence data. We processed the resultant data using the recently developed Livermore Metagenomics Analysis Toolkit (LMAT), a novel software platform for scalable metagenomic taxonomy classification using a local reference genome database.

\section{Results}

Microorganisms detected in wound samples by LLMDA. Initial studies in year one of this project encountered challenges relating to the high level of background human DNA present in these samples. We have since optimized sample preparation and performed all subsequent hybridizations using the updated LLMDA v5 platform. This platform yielded more specific 
results, and provided for more sensitive detection even in the presence of large quantities of “contaminating” host DNA.

Fifty percent of the 131 wound samples analyzed via the LLMDA yielded at least one detected organism upon analysis (Table 1). Of these array-positive samples, 29\% were indicated to contain more than one microbial species. Select samples had also been previously interrogated for bacterial presence via quantitative culture as part of a separate ongoing study. Of the culturenegative samples, 37\% were indicated to contain at least one bacterial species via LLMDA. While the received tissue and effluent samples were not always matched (ie. not necessarily obtained from the same individual at the same time point), it was observed that certain organisms, such as Pseudomonas, were more commonly observed in effluent, while others, such as Klebsiella and Enterobacter were more frequently found in tissue (Figure 1). Acinetobacter were represented prominently in both samples types. Complete array results and corresponding culture data are given in Appendix A. Several cases exist where LLMDA detection does not correspond precisely with cultured organism. However, as will be noted in observations from aim 2, LLMDA detection status correlates with the host response more accurately than culture status, indicating that detection of microorganisms by LLMDA provides a superior predictive profile of wound status.

The most commonly observed group of organisms included those belonging to the Acinetobacter genus, represented in 38 samples (29\%), with 28 of these being indicated to specifically contain Acinetobacter baumannii (Table 1). Detection of A. baumannii often occurred in the context of multiple detected strains, which may indicate either co-colonization or the presence of a novel, unsequenced strain. Other bacterial species that were detected in more than 3\% of samples were Escherichia coli (5.3\%), Klebsiella pneumoniae (4.6\%), Borrelia afzelii (3.8\%), Enterobacter cloacae (3.8\%), and Salmonella enterica (3.1\%).

Table 1. Microorganisms detected in wound samples by LLMDA.

\begin{tabular}{cc|cc}
\hline Microorganism & $\begin{array}{c}\text { Number of positive } \\
\text { samples }\end{array}$ & Microorganism & $\begin{array}{c}\text { Number of positive } \\
\text { samples }\end{array}$ \\
\hline Acinetobacter sp. & 30 & Uncultured bacterium plasmid pB10 & 2 \\
Acinetobacter baumannii & 28 & Achromobacter xylosoxidans & 1 \\
Escherichia coli & 7 & Aspergillus niger & 1 \\
Klebsiella pneumoniae & 6 & Bacteroides plebeius & 1 \\
Borrelia afzelii & 5 & Bordetella avium & 1 \\
Enterobacter cloacae & 5 & Corynebacterium bovis & 1 \\
HPV 57 & 5 & Enterobacter asburiae & 1 \\
HPV 71 & 5 & Enterococcus faecium & 1 \\
HHV 6A & 4 & Pasteurella multocida & 1 \\
Salmonella enterica & 4 & Pseudomonas entomophila & 1 \\
Bacteroides fragilis & 3 & Pseudomonas putida & 1 \\
Human parvovirus & 3 & Pseudomonas stutzeri & 1 \\
Mycobacterium abscessus & 3 & Roseburia hominis & 1 \\
Pseudomonas sp. & 3 & Salmonella enteritidis & 1 \\
Bacillus cereus & 2 & Shigella sonnei & 1 \\
Pseudomonas aeruginosa & 2 & Staphylococcus aureus & 1 \\
Ralstonia solanacearum & 2 & Staphylococcus epidermidis & 1 \\
Staphylococcus lugdunensis & 2 & & 1 \\
Streptomyces sp. & 2 & & \\
\hline
\end{tabular}


Figure 1. Microorganisms detected in wound tissue or effluent by LLMDA.

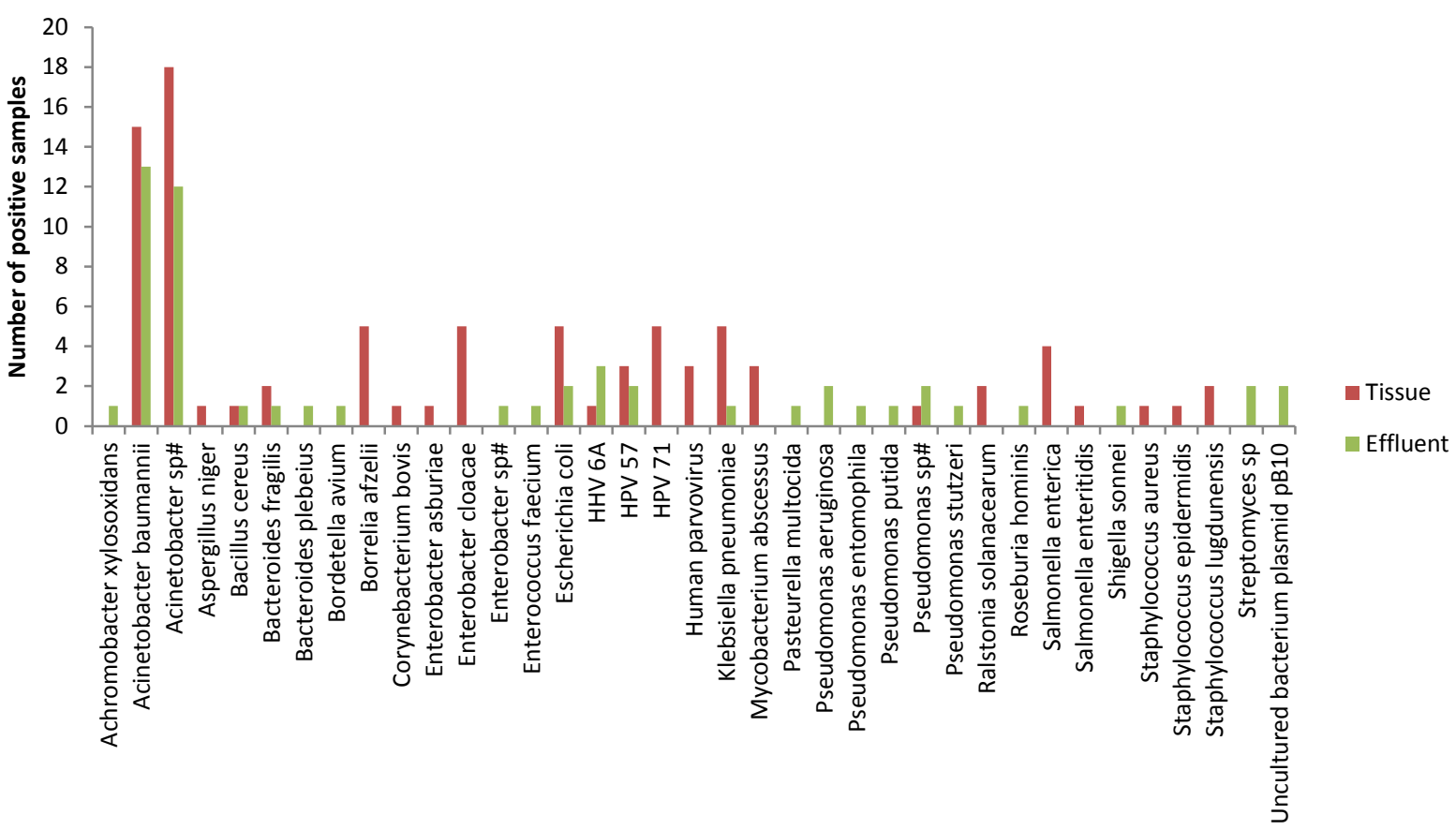

Microorganisms detected by next-generation sequencing. DNA from a pilot set of six samples was subjected to next-generation sequencing (Table 2). All data were analyzed using the Livermore Metagenomics Analysis Toolkit and visualized using Krona [9]. Results revealed distinct differences both in the composition and relative diversity between individual wound samples. Due to a high degree of human cellular content in these samples, and our whole genome sequencing approach, a large proportion, approximately $75 \%$, of total reads aligned to the human genome. Reads corresponding to bacterial genomes represented between 0.5 and $9.0 \%$ of total sequence data.

Table 2. Samples selected for next-generation sequencing pilot run.

\begin{tabular}{|c|c|c|c|c|c|}
\hline Sample & Type & Culture growth & Array detection & $\begin{array}{l}\text { Wound } \\
\text { status }\end{array}$ & $\begin{array}{l}\text { \% Bacterial } \\
\text { reads }\end{array}$ \\
\hline KS702EBON & Effluent & None & $\begin{array}{l}\text { Acinetobacter baumannii } \\
\text { Escherchia coli } \\
\text { Shigella sonnei }\end{array}$ & Dehisced & 9 \\
\hline IS712EBON & Effluent & None & $\begin{array}{l}\text { Acinetobacter baumannii } \\
\text { Pseudomonas aeruginosa }\end{array}$ & Dehisced & 4 \\
\hline IS712WA & Tissue & None & $\begin{array}{l}\text { Enterobacter cloacae } \\
\text { Staphylococcus lugdunensis } \\
\text { Borrelia afzelii }\end{array}$ & Dehisced & 0.6 \\
\hline JT691ECON & Effluent & None & $\begin{array}{l}\text { Acinetobacter baumannii } \\
\text { Pseudomonas putida } \\
\text { Pseudomonas entomophila }\end{array}$ & Dehisced & 5 \\
\hline JG352EA2 & Effluent & $\begin{array}{l}\text { Acinetobacter sp. } \\
\text { Alloicoccus otidis }\end{array}$ & None & Dehisced & 0.6 \\
\hline TN631WB & Tissue & Enterococcus faecium & None & Healed & 0.5 \\
\hline
\end{tabular}


Sequence data derived from array-positive samples demonstrated lower overall microbial diversity relative to those in which no organisms were detected via orthogonal techniques. In array-positive samples, over $50 \%$ of total bacterial sequence data aligned to two or fewer individual species. In sequence derived from sample KS702EBON, in which A. baumannii was the top array hit, $45 \%$ of sequenced reads corresponded to this species. Similarly, in sample IS712EBON, 71\% of sequenced reads aligned to the array-detected species $P$. aeruginosa and $4 \%$ to A. baumannii (Figure 2). The samples that were observed to be microbe-negative according to the detection array showed broader diversity, and were more representative of the broader microbiome (Appendix B).

Figure 2. Hierarchical charts demonstrating bacterial species detected by analysis of metagenomic sequence data. Left. Sample KS702EBON. Right. Sample IS712EBON
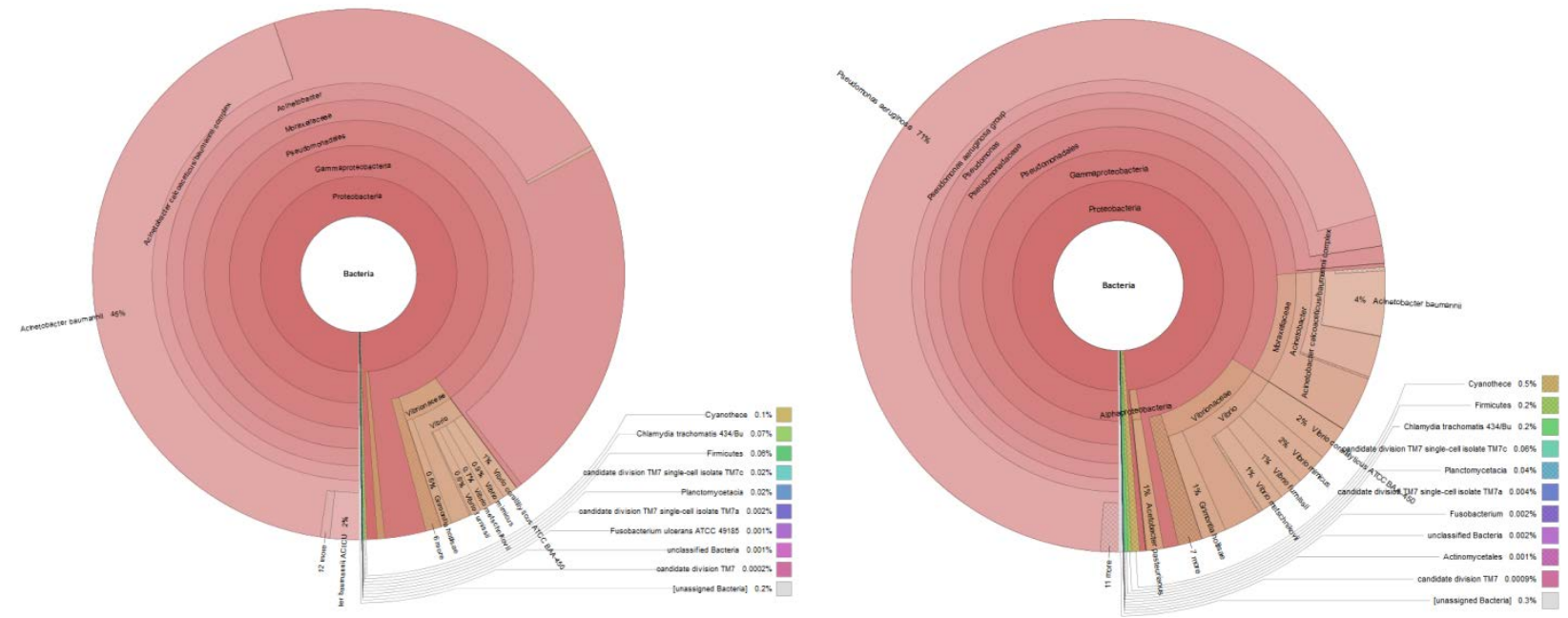

For sequencing identification at the strain level, identified strains and sub-strains largely correlated with those identified using the LLMDA (Table 3). In particular, the most common strains belonging to the A. baumannii group detected by the array included strains 6013150 , ACICU, and AB0057. These three subtypes were also the most frequently observed via nextgeneration sequencing. These observations support the use of the array technology for rapid, low-resolution genotyping. In many cases, multiple A. baumannii strains were identified both by detection array and sequencing. This may indicate co-colonization by multiple strains, but could also point toward the presence of a unique unidentified $A$. baumannii strain. 
Table 3. A. baumannii strains detected in sample KS702EBON by LLMDA and sequencing.

\begin{tabular}{ll}
\hline Strains/plasmids detected by LLMDA & Strains detected by sequencing \\
\hline Acinetobacter sp. $\mathbf{6 0 1 3 1 5 0}$ & Acinetobacter baumannii ACICU \\
\hline Acinetobacter baumannii plasmid ACICU & Acinetobacter baumannii 6013150 \\
Acinetobacter baumannii plasmid pAB0057 & Acinetobacter baumannii AB0057 \\
\hline Acinetobacter baumannii plasmid pRAY & Acinetobacter baumannii TCDC-AB0715 \\
Acinetobacter baumannii AB307-0294 & Acinetobacter baumannii MDR-ZJ06 \\
Acinetobacter baumannii plasmid pAB2 & Acinetobacter baumannii 6014059 \\
& Acinetobacter baumannii 6013113 \\
& Acinetobacter baumannii AB900 \\
& Acinetobacter baumannii ATCC 17978 \\
& Acinetobacter baumannii SDF \\
& Acinetobacter baumannii ATCC 19606 \\
& Acinetobacter baumannii 1656-2 \\
& Acinetobacter baumannii AB307-0294 \\
\hline
\end{tabular}

Our observed results underscore the importance of a more comprehensive microbial detection strategy. As was noted, many of the microorganisms detected by the LLMDA and sequencing were not cultured via standard techniques. Additionally, a number of microorganisms not previously implicated in wound or hospital-acquired infections were identified to be present. These organisms may very well play an as-of-yet unrecognized but important role in wound healing, which could be highly relevant to the course of treatment for a patient.

\section{Technical challenges and practiced mitigation}

1. Sample preparation methods initially applied in this project were deemed non-ideal for nucleic acid analysis due to incomplete homogenization of the sample and protocols that may not have been sufficient for complete disruption of gram-positive bacteria. More extensive disruption protocols were therefore applied, including thorough bead beating, high-speed vortexing, and high temperature proteolytic lysis.

2. When subjected to sequencing, DNA extracts derived from wound tissue samples yielded high percentages ( $>99 \%)$ of human DNA sequence data. Future sequencing runs will therefore focus on effluent samples, as they demonstrated larger percentages of bacterial sequence data, in addition to being more clinically accessible.

\section{Aim 2: Identification of biomarkers for host responses in combat wounds (UC Davis, Naval Medical Research Center)}

\section{Methods}

High abundant protein removal. Depletion of high abundant proteins was performed according to the manufacturer's instructions (Agilent Technologies). Briefly, human effluent or serum was diluted five-fold in Buffer A and centrifuged through a 0.22 micron spin filter tube at $16,000 \mathrm{x}$ g for $5 \mathrm{~min}$ to remove particulates. Then effluent fluid or serum was processed using Multiple Affinity Removal Column Human-6, which specifically removes albumin, IgA, IgG, antitrypsin, transferrin and haptoglobin. A low abundant protein fraction was collected for each sample. Fractions were concentrated by precipitating with an equal volume of $20 \%$ trichloroacetic acid solution and incubated at $4^{\circ} \mathrm{C}$ for $30 \mathrm{~min}$. Precipitate was centrifuged and 
washed, allowed to air dry, and then resuspended in DIGE labeling buffer. Protein quantification was performed using Precision Red Advanced Protein Assay Reagent (Cytoskeleton).

2-D DIGE. Crude and high abundant protein depleted effluent and serum samples were separated in 2 dimensions according to the GE Life Sciences Ettan DIGE system protocol. Briefly, each sample (50 $\mu \mathrm{g}$ ) was minimally labeled with Cy2, Cy3 or Cy5 for $30 \mathrm{~min}$. The samples were pooled together and added to rehydration buffer. Sample was loaded onto $24 \mathrm{~cm}$ ph3-10NL Immobiline DryStrips (GE Life Sciences) and focused by active overnight rehydration, followed by isoelectric focusing for a total of 62,500 Vhrs. Strips were equilibrated with $10 \mathrm{mg} / \mathrm{ml}$ DTT for $15 \mathrm{~min}$ followed by $25 \mathrm{mg} / \mathrm{ml}$ for $15 \mathrm{~min}$ with iodoacetamide, then applied to DIGE gels (GE Life Sciences) for 2nd dimension separation. The resulting CyDye labeled protein gels were scanned using 100 micron resolution on Typhoon 9410 (GE Life Sciences). Data analysis was carried out using DeCyder 2D 7.0 software (GE Life Sciences). Spot detection and abundance quantification was performed using the differential in-gel analysis (DIA) module of DeCyder.

\section{Results}

2-D DIGE analysis of effluent and serum after high abundant protein removal. Combat wound samples sent from NMRC to UC Davis were processed using the empirically-determined optimized protocols described above. Our results highlight 2-D DIGE results that compare both sample types and characterize the proteomes, comprising 1,800 and 1,200 protein spots, respectively. Furthermore, we show that high abundant protein removal is necessary for both serum and wound effluent to obtain reproducible results. Figure 3 shows typical wound effluent (panel A) and serum (panel B) 2-D DIGE images following high-abundant protein removal. High abundant protein removal enables the appearance of numerous lower abundant proteins that are now detectable. We have further established these methods to be used in putative biomarker discovery between samples that heal and samples that do not heal.

Figure 3. Overlay 2-D DIGE Images of Wound Effluent (A) and Serum (B). Images show a significant number of protein spots that are increased over these samples prior to high abundant protein removal.
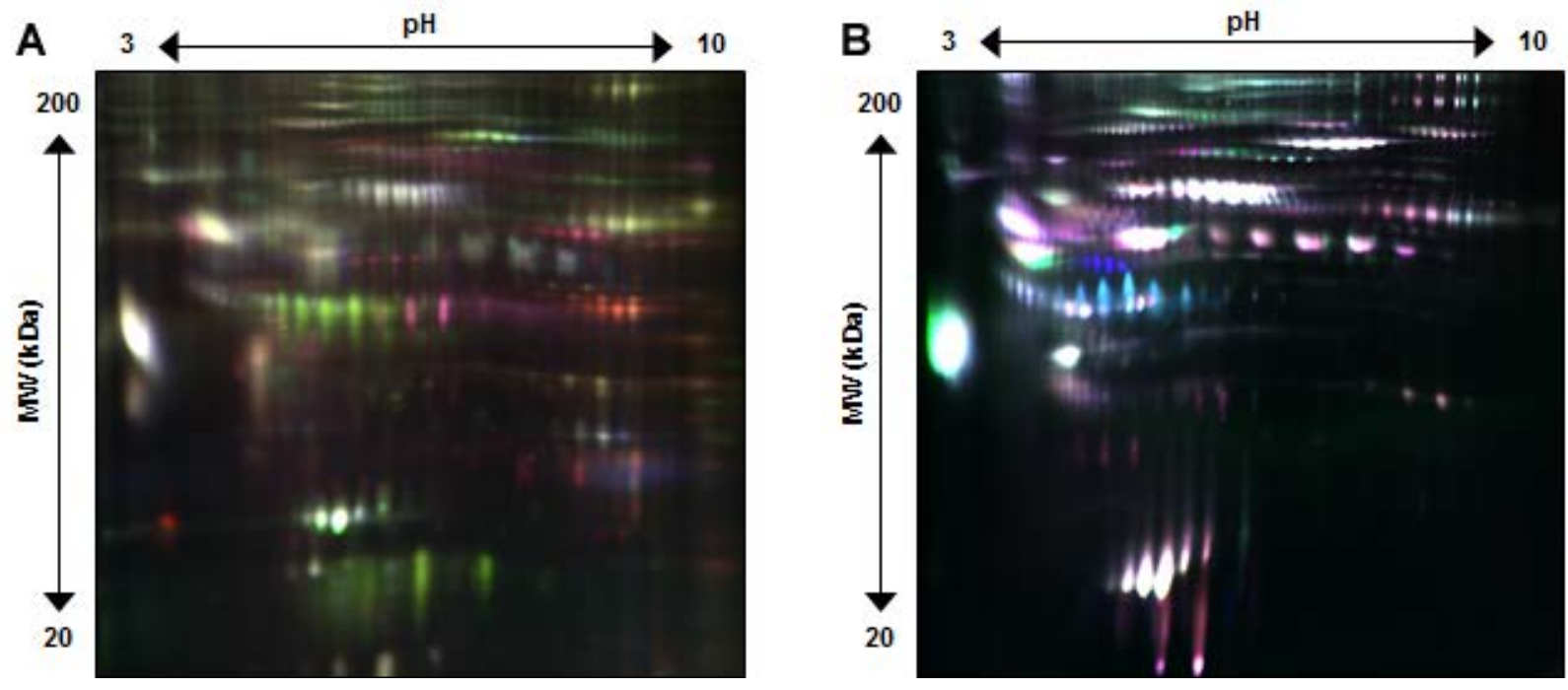
Differential protein expression determined by 2-D DIGE. In addition to our efforts on improving proteomic sample preparation for these samples, we also were able to find putative biomarkers in both sample types. For the wound effluent samples, there were 52 protein spots that were found to be differentially expressed when comparing healed vs. dehisced. These 52 proteins were identified by mass spectrometry and were analyzed for their expression pattern. Figure 4 shows the types of protein expression changes and provides five categories for expression that these proteins can be grouped into based on their expression level changes. The grouped proteins that show similar expression patterns may be similar in function, as well.

Figure 4. Differentially expressed proteins can be clustered by expression pattern. Protein identification and function are shown for these differentially expressed proteins to highlight potential pathways involved in wound healing. Each of these proteins can be further studied to examine mechanism of their activity.

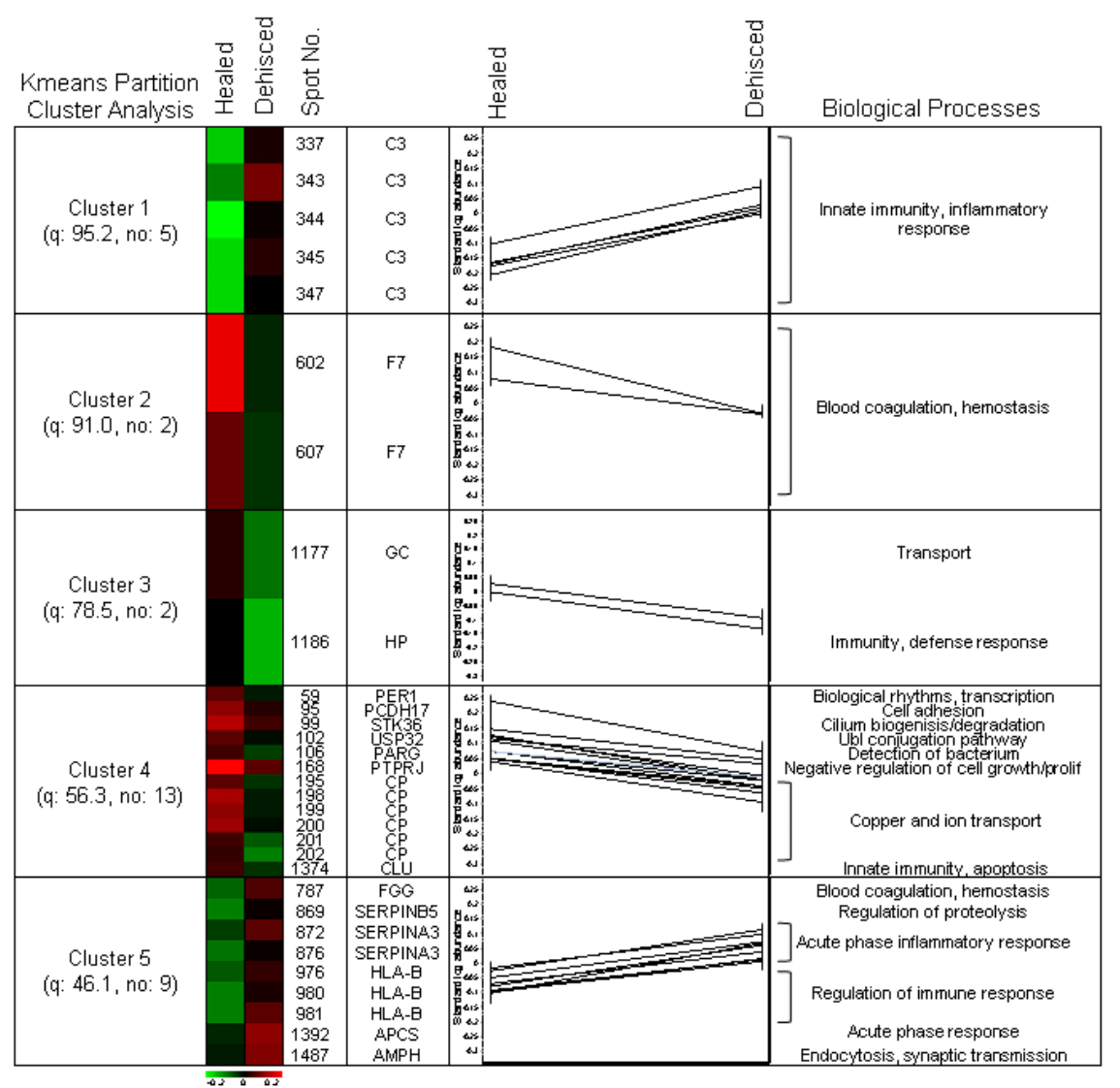

PCA analysis of differential protein expression based on bacterial culture or microbial detection array results. Additional proteomic comparisons were made involving samples that contained bacteria as compared to those that were free of bacterial contamination. When comparing bacteria-negative to bacteria-positive samples using culture as a discriminator and the LLNL array detection platform (LLMDA), we found 74 and 95 differentially expressed protein spots, respectively. These proteins were also examined for clustering and proteins were identified for functional classification. 
Subsequently, both PCA and discrimination analysis of these samples were completed, showing evidence that the LLMDA determination of bacterial status provides a more distinct separation between samples than does the use of culture for determining host protein changes. Figure 5 shows the PCA analysis of these results, in which separating samples by culture status did not provide sufficient clustering of the proteomes, but when samples were clustered by presence of bacterial DNA as determined by LLMDA, a clear distinction of protein expression pattern is indicated by the PCA analysis.

\section{Figure 5. PCA analysis shows improved proteome clustering in LLMDA determination of bacterial presence (right) as compared to culturing (left).}
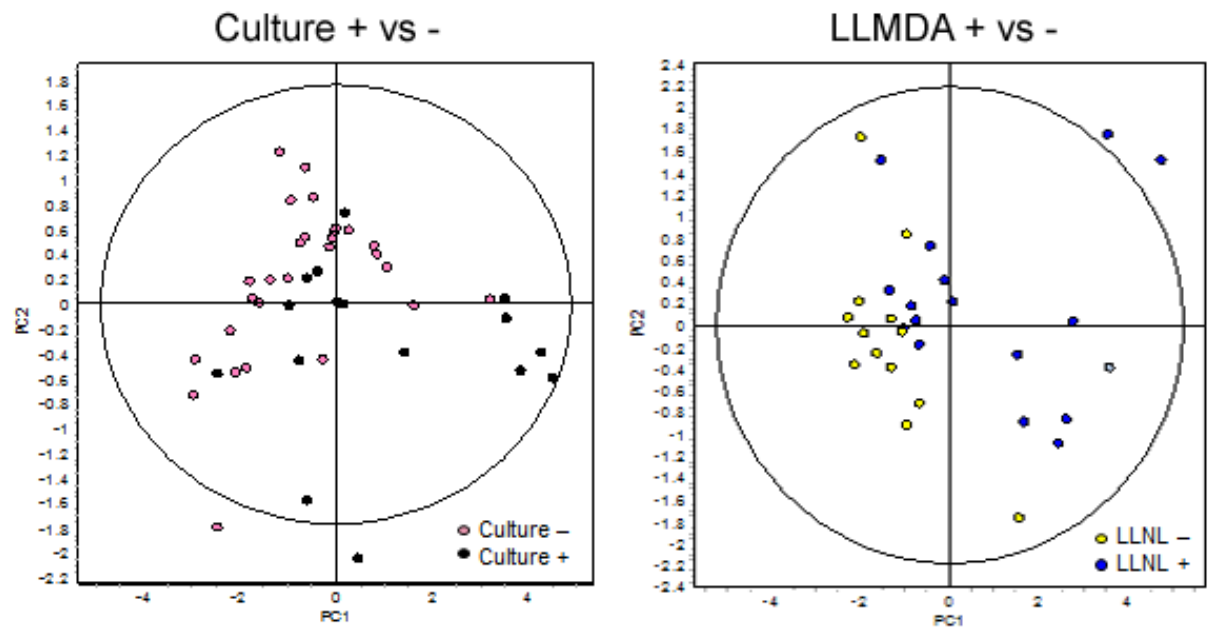

Differential protein expression based on healed vs. dehisced wound results. Finally, we completed marker discrimination (Discriminate Analysis) for each of these three comparisons, which provides a minimal set of protein biomarkers that are sufficient to classify between two different sample types. Differentially expressed proteins that were used to discriminate these proteome samples are part of a marker selection panel of protein spots whose expression greatly affects the designation of the proteome. These results show 9,10 , and 6 protein spots that provide a minimal marker set for discriminating between these three comparison types. The accuracy of using these markers for discriminating host proteome samples between one sample to another was also determined (Table 3). For example, there are 9 markers selected that could discriminate between healed and dehisced wound effluent sample at $84 \%$ accuracy. The protein identifications for these 9 markers are shown in Table 4. Most importantly, these proteins could be used in a biomarker panel to determine which sample type a particular host proteome belongs to. In addition, these proteins could potentially be developed into a diagnostic protein panel or confirmatory assay that could help guide clinical treatment. 
Table 3. Discriminate Analysis for Three Distinct Proteome Sample Comparisons. This table shows the differential proteins, markers selected, and the accuracy of the markers for discriminate analysis of wound effluent proteomes.

\begin{tabular}{|c|c|c|c|c|c|}
\hline Group & \multicolumn{2}{|c|}{$\begin{array}{c}\text { Comparison } \\
\text { (left vs. right) }\end{array}$} & $\begin{array}{c}\text { Differential } \\
\text { Proteins }\end{array}$ & $\begin{array}{c}\text { Markers } \\
\text { selected }\end{array}$ & Accuracy (\%) \\
\hline 1 & Healed & Dehisced & 52 & 9 & $83.83 \pm 2.8$ \\
\hline 2 & $\begin{array}{c}\text { Culture } \\
\text { Negative }\end{array}$ & $\begin{array}{c}\text { Culture } \\
\text { Positive }\end{array}$ & 74 & 10 & $70.31 \pm 16.3$ \\
\hline 3 & $\begin{array}{c}\text { LLNL } \\
\text { Negative }\end{array}$ & $\begin{array}{c}\text { LLNL } \\
\text { Positive }\end{array}$ & 95 & 6 & $76.67 \pm 7.0$ \\
\hline
\end{tabular}

Table 4. Identified Proteins For Discriminating Between Healed and Dehisced Proteome Samples. The listed proteins are the minimal set of proteins that indicate whether a proteome sample is a healed or dehisced sample based on their protein expression profile.

\begin{tabular}{|c|l|l|}
\hline \multicolumn{2}{|c|}{ Healed vs Dehisced Discriminate Markers } \\
\hline $\begin{array}{c}\text { Spot } \\
\text { No. }\end{array}$ & $\begin{array}{l}\text { Gene } \\
\text { Name }\end{array}$ & Protein Name \\
\hline 95 & PCH17 & Protocadherin 17 \\
\hline 99 & STK36 & $\begin{array}{l}\text { Serine/threonine } \\
\text { protein kinase 3 }\end{array}$ \\
\hline 168 & PTPRJ & $\begin{array}{l}\text { Receptor type tyrosine } \\
\text { protein phosphotase } \\
\text { precursor }\end{array}$ \\
\hline 195 & CP & Ceruloplasmin \\
\hline 198 & CP & Ceruloplasmin \\
\hline 341 & C3 & Complement C3 \\
\hline 343 & C3 & Complement C3 \\
\hline 375 & XPNPEP1 & $\begin{array}{l}\text { Xaa-Pro } \\
\text { aminopeptidase 1 }\end{array}$ \\
\hline 872 & SERPINA3 & $\begin{array}{l}\text { Alpha-1- } \\
\text { antichymotrypsin }\end{array}$ \\
\hline
\end{tabular}

\section{Aim 3: Data analysis and clinical correlations (LLNL, UC Davis, and Naval Medical Research center)}

Once Aims 1 and 2 are completed, LLNL will construct statistical models to predict clinical outcomes given (i) identified microbial flora and (ii) host response biomarkers. Standard multivariate regression methods will be used to predict categorical responses (wound closure vs. acute infection vs. chronic infection), and a Cox proportional hazard model will be applied to predict quantitative measures such as time to closure. LLNL and UC Davis have statisticians with 
the appropriate bioinformatics and clinical trials experience, respectively, for statistical analysis and computational modeling of the wound profiling data that will be generated in this project.

\section{KEY RESEARCH ACCOMPLISHMENTS}

\section{Aim 1:}

- Further optimized protocols for extraction of nucleic acid from wound tissue.

- 131 total tissue and effluent samples were provided to LLNL by NMRC. All samples were extracted and hybridized to the version 5 LLMDA at LLNL.

- Established detection of microorganisms in 50\% of tissue samples, including 38\% of samples identified as culture-negative by standard microbiological techniques

- Achieved species-level identification for most organisms detected in wound samples.

- Performed pilot next-generation sequencing run on six wound samples and processed data using a novel metagenomics analysis platform.

- Determined sample type most likely to yield high quality pathogen sequence data in future sequencing runs.

\section{Aim 2:}

- Determined ideal sample quantity and storage medium prior to analysis via 2D-DIGE.

- Optimized sample preparation methods and run parameters for 2D-DIGE.

- Determined that a large quantity of protein spots are obtained following analysis of preliminary burn wound samples.

- Identified several protein spots in preliminary samples whose presence was differentially observed between different sample groups, supporting the feasibility of this method for the discovery of possible biomarker candidates.

- Identified 122 protein spots with greater than 1.2 fold change in healed vs. dehisced or culture negative vs. culture positive wound effluent and p-value $<0.05$.

- Found 52, 74, and 95 putative protein biomarkers among three comparisons (healed v. dehisced, culture positive vs. culture negative, and LLMDA positive v. LLMDA negative), respectively

- Used proteomic bioinformatics tools including hierarchical clustering and determinant analysis to refine putative biomarker panels providing 70-80\% accuracy and 6-10 proteins for each of these comparisons.

- PCA analysis of proteome samples show that LLMDA provides a clearer distinction between proteomes than culture status, suggesting that correlation of LLMDA detection to host response may be beneficial for future diagnostic and other clinical implications.

\section{REPORTABLE OUTCOMES}

\section{Invited oral presentations:}

Be NA, Chromy BA, Brown TS, Eldridge A, Gardner SN, McLoughlin KS, Luciw PA, Elster EA, Jaing C. Profiling of combat wounds through microbial and host biomarker detection. In: Gordon Research Seminar: Chemical and Biological Terrorism Defense; Ventura, CA; 2013 Mar 9-10. 
Poster presentations at professional meetings:

Be NA, Brown TS, Chromy BA, Gardner SN, McLoughlin KS, Elster EA, Jaing C. Detection of microbial colonization in combat wounds. In: Military Health System Research Symposium; Fort Lauderdale, FL; 2012 Aug 13-16; Abstract 4, Infection Control and Treatment.

Be NA, Gardner S, McLoughlin K, Thissen JB, Slezak T, Jaing C. A comprehensive microbial detection array applied to biodefense and public safety. In: $5^{\text {th }}$ National Bio-Threat Conference; Denver, Colorado; 2012 March 27-29.

\section{Manuscripts in preparation:}

Chromy BA, et al. Proteomic Sample Preparation for Analysis of Host Responses to Blast Wounds.

Be NA, et al. Molecular profiling of combat wound infection through microbial detection microarray and next-generation sequencing.

\section{CONCLUSION}

Our studies, employing the advanced LLMDA, next-generation sequencing, and 2DDIGE proteomic technologies, have identified a broad range of wound-relevant pathogens and host biomarkers in tissue and effluent samples from wound biopsies. In particular, detection of microorganisms in samples previously believed to be culture-negative is highly relevant toward the purpose of this project, to identify wound pathogen profiles which cannot be effectively obtained through standard microbiological techniques. It is likely that a large proportion of wounds contain unculturable organisms, particularly those species involved in biofilm formation or which exhibit drug resistance. Our proteomics analysis yielded a defined set of potential biomarkers that are indicative of the host response and predictive of wound resolution and healing. In combination with our derived microbial information, these profiles will provide highly valuable information toward novel wound characterization and clinical outcome classification.

Continuing work will address a number of project points. We plan to sequence an additional 12 samples, focusing on effluent collected during wound debridements, as these sample types yielded the most practically useful sequence data, and are amenable to straightforward collection in the field. The whole genome sequence data will be analyzed for bacterial, viral, and fungal detection. Additionally, proteomic data will be compiled and host biomarkers identified. Statistical models will be constructed to identify the most informative microbial and host biomarkers and assays for detection of these factors will be designed.

In both the military and clinical fields, treatment of wound infections still relies heavily on conventional microbiology, which is not powered to reliably assess the full spectrum of factors involved in patient recovery. Our technical resources allow us to assess an abundantly comprehensive range of infectious organisms and host proteins, constructing a truly complete wound profile. This information, applied to clinical practice, will allow for acquisition of a much clearer picture of the complex host-pathogen interactions vital to the wound healing 
process. Such information is crucial to effective case management for service members and other patients undergoing wound treatment.

\section{REFERENCES}

1. Bowler PG, Duerden BI and Armstrong DG. Wound microbiology and associated approaches to wound management. Clin Microbiol Rev 2001;14:244-69

2. McGuckin M, Goldman R, Bolton L and Salcido R. The clinical relevance of microbiology in acute and chronic wounds. Adv Skin Wound Care 2003;16:12-23; quiz 24-5

3. Thomson PD. Immunology, microbiology, and the recalcitrant wound. Ostomy Wound Manage 2000;46:77S-82S; quiz 83S-84S

4. Davies CE, Hill KE, Wilson MJ, et al. Use of $16 \mathrm{~S}$ ribosomal DNA PCR and denaturing gradient gel electrophoresis for analysis of the microfloras of healing and nonhealing chronic venous leg ulcers. J Clin Microbiol 2004;42:3549-57

5. Forsberg JA, Elster EA, Andersen RC, et al. Correlation of procalcitonin and cytokine expression with dehiscence of wartime extremity wounds. J Bone Joint Surg Am 2008;90:580-8

6. Brown TS, Hawksworth JS, Sheppard FR, Tadaki DK and Elster E. Inflammatory response is associated with critical colonization in combat wounds. Surg Infect (Larchmt) 2011;12:351-7

7. Utz ER, Elster EA, Tadaki DK, et al. Metalloproteinase Expression is Associated with Traumatic Wound Failure. J Surg Res 2009

8. Gardner SN, Jaing CJ, McLoughlin KS and Slezak TR. A microbial detection array (MDA) for viral and bacterial detection. BMC Genomics 2010;11:668

9. Ondov BD, Bergman NH and Phillippy AM. Interactive metagenomic visualization in a Web browser. BMC Bioinformatics 2011;12:385 


\section{APPENDIX A.}

\section{Microorganisms detected by LLMDA in each of 131 wound tissue and effluent samples collected during debridement procedures.}

$\mathrm{NG}=$ no growth

UNK = unknown culture status

*Organism detected by LLMDA at lower stringency threshold (0.95)

\begin{tabular}{|c|c|c|c|c|}
\hline Sample & Type & Wound outcome & NMRC cultured organism & LLMDA detected (array version 5) \\
\hline BM081WAL & Tissue & Healed & Pseudomonas stutzeri & $\begin{array}{l}\text { Pseudomonas sp.* } \\
\text { Mycobacterium abscessus* } \\
\text { Salmonella enterica* } \\
\text { Klebiella pneumoniae* } \\
\text { Enterobacter cloacae plasmid pCHE-A* } \\
\text { HPV 71* }\end{array}$ \\
\hline BM081WCL & Tissue & Healed & Citrobacter freundii & Acinetobacter sp. SUN plasmid pRAY \\
\hline CG531WA & Tissue & Healed & NG & Acinetobacter sp. Plasmid pRAY \\
\hline DE041WA & Tissue & Dehisced & Acinetobacter baumannii & $\begin{array}{l}\text { Acinetobacter sp.* } \\
\text { Acinetobacter plasmid pRAY } \\
\text { Acinetobacter baumannii plasmid pACICU2* } \\
\text { Acinetobacter baumannii plasmid pABIR }\end{array}$ \\
\hline DE041WCL & Tissue & Dehisced & Acinetobacter baumannii & $\begin{array}{l}\text { Acinetobacter sp. } 6014059 \\
\text { Acinetobacter sp. SUN plasmid pRAY } \\
\text { Acinetobacter baumannii ACICU plasmid pACICU2 } \\
\text { Acinetobacter baumannii plasmid pABIR }\end{array}$ \\
\hline DE042WC & Tissue & Dehisced & Acinetobacter baumannii & $\begin{array}{l}\text { Acinetobacter baumannii plasmid pABIR } \\
\text { Acinetobacter sp. SUN plasmid pRAY } \\
\text { Acinetobacter baumannii ACICU plasmid pACICU2 } \\
\text { Corynebacterium bovis }\end{array}$ \\
\hline DE043WAL & Tissue & Dehisced & Acinetobacter baumannii & $\begin{array}{l}\text { Acinetobacter sp.* } \\
\text { Acinetobacter plasmid pRAY } \\
\text { Acinetobacter baumannii plasmid pACICU2* } \\
\text { Acinetobacter baumannii plasmid pABIR } \\
\text { Klebsiella pneumoniae plasmid* }\end{array}$ \\
\hline DL111WAL & Tissue & Healed & NG & None detected \\
\hline DL111WF & Tissue & Healed & $\begin{array}{l}\text { Acinetobacter baumannii } \\
\text { Enterococcus faecium }\end{array}$ & None detected \\
\hline DM231WB & Tissue & Healed & NG & None detected \\
\hline EB471WA & Tissue & Dehisced & Acinetobacter baumannii & Acinetobacter SUN plasmid pRAY \\
\hline EB471WC & Tissue & Dehisced & UNK & Acinetobacter sp. SUN plasmid pRAY \\
\hline ET662WB & Tissue & Dehisced & NG & None detected \\
\hline GJ131WAL & Tissue & Healed & Escherichia coli & $\begin{array}{l}\text { Bacteroides fragilis NCTC } 9343^{*} \\
\text { HPV } 57^{*}\end{array}$ \\
\hline GJ131WC & Tissue & Healed & NG & None detected \\
\hline HP561WA & Tissue & Healed & NG & None detected \\
\hline HP561WB & Tissue & Healed & NG & $\begin{array}{l}\text { Ralstonia solanacearum* } \\
\text { HHV } 6 \text { A }\end{array}$ \\
\hline IS711WA & Tissue & Dehisced & NG & None detected \\
\hline IS711WB & Tissue & Dehisced & Stenotrophomonas maltophilia & None detected \\
\hline IS712WA & Tissue & Dehisced & NG & $\begin{array}{l}\text { Enterobacter cloacae plasmid pECO1 } \\
\text { Staphylococcus lugdunensis } \\
\text { Borrelia afzelii }\end{array}$ \\
\hline IS712WB & Tissue & Dehisced & NG & $\begin{array}{l}\text { Acinetobacter sp. Plasmid pRAY } \\
\text { Staphylococcus aureus } \\
\text { Staphylococcus epidermidis } \\
\text { Staphylococcus lugdunensis }\end{array}$ \\
\hline JC271WA & Tissue & Healed & Enterococcus faecium & $\begin{array}{l}\text { Klebsiella pneumoniae plasmid* } \\
\text { Escherichia coli KO11 plasmid * } \\
\text { Enterobacter asburiae* } \\
\text { HPV 57* }\end{array}$ \\
\hline JC271WB & Tissue & Healed & NG & None detected \\
\hline
\end{tabular}




\begin{tabular}{|c|c|c|c|c|}
\hline JC272WA & Tissue & Healed & Enterococcus faecium & $\begin{array}{l}\text { Salmonella enterica* } \\
\text { HPV71* }\end{array}$ \\
\hline JC272WA & Tissue & Healed & Enterococcus faecium & Aspergillus niger* \\
\hline JC272WB & Tissue & Healed & NG & None detected \\
\hline JD681WA & Tissue & Dehisced & NG & None detected \\
\hline JD681WB & Tissue & Dehisced & Enterococcus faecium & None detected \\
\hline JG351WA & Tissue & Dehisced & $\begin{array}{l}\text { Acinetobacter sp. } \\
\text { Bacillus cereus }\end{array}$ & $\begin{array}{l}\text { Acinetobacter sp. SUN plasmid pRAY } \\
\text { Human parvovirus B19 }\end{array}$ \\
\hline JG352WA & Tissue & Dehisced & $\begin{array}{l}\text { Acinetobacter sp. } \\
\text { Alloicoccus otidis }\end{array}$ & None detected \\
\hline JR281WA & Tissue & Healed & $\begin{array}{l}\text { Acinetobacter } \\
\text { baumannii/calcoaceticus } \\
\text { complex }\end{array}$ & Acinetobacter sp. Plasmid pRAY \\
\hline JR281WA & Tissue & Healed & $\begin{array}{l}\text { Acinetobacter } \\
\text { baumannii/calcoaceticus } \\
\text { complex }\end{array}$ & None detected \\
\hline JR281WC & Tissue & Healed & NG & $\begin{array}{l}\text { Acinetobacter sp. SUN plasmid pRAY } \\
\text { Acinetobacter baumannii ATCC } 17978 \text { plasmid pAB1 } \\
\text { Human parvovirus B19 }\end{array}$ \\
\hline JR341WA & Tissue & Healed & Acinetobacter baumannii & $\begin{array}{l}\text { Mycobacterium abscessus* } \\
\text { HPV } 71 * \\
\text { Salmonella enterica* } \\
\text { Borrelia afzelii* }\end{array}$ \\
\hline JR341WB & Tissue & Healed & NG & $\begin{array}{l}\text { Acinetobacter sp. SUN plasmid pRAY } \\
\text { Acinetobacter baumannii plasmid pABIR } \\
\text { Human parvovirus B19 }\end{array}$ \\
\hline JR342WA & Tissue & Dehisced & Acinetobacter baumanii & $\begin{array}{l}\text { Acinetobacter sp. Plasmid pRAY } \\
\text { Acinetobacter baumannii ACICU plasmid }\end{array}$ \\
\hline JR342WH & Tissue & Dehisced & NG & $\begin{array}{l}\text { Acinetobacter baumannii AB0057 plasmid pAG0057 } \\
\text { Acinetobacter baumannii AYE plasmid p4ABAYE } \\
\text { Acinetobacter baumannii ATCC } 17978 \text { plasmid AB2 }\end{array}$ \\
\hline JT691WB & Tissue & Dehisced & Staphyllococcus capitis & Acinetobacter SUN pRAY \\
\hline JT691WC & Tissue & Dehisced & $N G$ & $\begin{array}{l}\text { Ralstonia solanacearum* } \\
\text { Mycobacterium abscessus* } \\
\text { Borrelia afzelii* }\end{array}$ \\
\hline KS702WA & Tissue & Dehisced & NG & None detected \\
\hline KS702WB & Tissue & Dehisced & NG & None detected \\
\hline LM671WA & Tissue & Dehisced & NG & None detected \\
\hline LM671WB & Tissue & Dehisced & UNK & None detected \\
\hline MS201WA & Tissue & Healed & $\begin{array}{l}\text { Acinetobacter baumannii } \\
\text { Achromobacter sp. }\end{array}$ & $\begin{array}{l}\text { HPV } 57^{*} \\
\text { Borrelia afzelii* }\end{array}$ \\
\hline MS201WJ & Tissue & Healed & NG & Acinetobacter baumannii plasmid pABIR \\
\hline MW651WA & Tissue & Healed & NG & None detected \\
\hline MW651WB & Tissue & Healed & UNK & None detected \\
\hline PH221WA & Tissue & Healed & Acinetobacter baumannii & $\begin{array}{l}\text { Acinetobacter baumannii AB0057 plasmid pAB0057 } \\
\text { Acinetobacter baumannii plasmid pABVA01 } \\
\text { Acinetobacter baumannii ATCC } 17978 \text { plasmid pAB2 } \\
\text { Acinetobacter baumannii AYE plasmid p2ABAYE }\end{array}$ \\
\hline RH491WA & Tissue & Healed & NG & None detected \\
\hline RW011WA & Tissue & Healed & $\begin{array}{l}\text { Acinetobacter baumannii (pan } \\
\text { resistant) }\end{array}$ & $\begin{array}{l}\text { Acinetobacter sp. SUN plasmid pRAY } \\
\text { Escherichia coli plasmid p9123 } \\
\text { Klebsiella pneumoniae plasmid pKpn114 } \\
\text { Escherichia coli E24377A plasmid pETEC6 }\end{array}$ \\
\hline RW011WCL & Tissue & Healed & $\begin{array}{l}\text { Acinetobacter baumannii (pan } \\
\text { resistant) }\end{array}$ & $\begin{array}{l}\text { Escherichia coli plasmid p9123 } \\
\text { Klebsiella pneumoniae plasmid pKpn114 } \\
\text { Salmonella enteritidis plasmid pK } \\
\text { Escherichia coli E24377A plasmid pETEC_6 } \\
\text { Escherichia coli plasmid pVI678 } \\
\text { Acinetobacter sp. SUN plasmid pRAY } \\
\text { Acinetobacter baumannii plasmid pABIR }\end{array}$ \\
\hline TN631WA & Tissue & Healed & NG & None detected \\
\hline
\end{tabular}




\begin{tabular}{|c|c|c|c|c|}
\hline TN631WB & Tissue & Healed & Enterococcus faecium & $\begin{array}{l}\text { HPV } 71^{*} \\
\text { Salmonella enterica* } \\
\text { borrelia afzelii* }\end{array}$ \\
\hline ZB191WA & Tissue & Healed & Acinetobacter baumannii & HPV71* \\
\hline ZB191WB & Tissue & Healed & $\begin{array}{l}\text { Enterobacter cloacae } \\
\text { Acinetobacter baumannii }\end{array}$ & $\begin{array}{l}\text { Acinetobacter baumannii plasmid pABIR } \\
\text { Enterobacter cloacae plasmid pECO1 } \\
\text { Escherichia coli plasmid pIGRW12 }\end{array}$ \\
\hline ZB191WB & Tissue & Healed & $\begin{array}{l}\text { Enterobacter cloacae } \\
\text { Acinetobacter baumannii }\end{array}$ & Enterobacter cloacae plasmid pEC01* \\
\hline ZB191WF & Tissue & Healed & NG & Acinetobacter sp. SUN plasmid pRAY \\
\hline ZB192WA & Tissue & Healed & Acinetobacter baumannii & $\begin{array}{l}\text { Acinetobacter sp. } 6014059 \\
\text { Acinetobacter baumannii ACICU } \\
\text { Acinetobacter baumannii } \\
\text { Enterobacter cloacae plasmid pEC01 } \\
\text { Escherichia coli plasmid plGRW12 }\end{array}$ \\
\hline ZB192WC & Tissue & Healed & NG & Acinetobacter baumannii plasmid pABIR \\
\hline CE742EA2 & Effluent & Healed & NG & None detected \\
\hline CG531EA2 & Effluent & Healed & NG & None detected \\
\hline CL461EA2 & Effluent & Healed & NG & None detected \\
\hline CM511EA2 & Effluent & Healed & NG & None detected \\
\hline CU501EA2 & Effluent & Dehisced & NG & None detected \\
\hline CU502EA2 & Effluent & Healed & NG & None detected \\
\hline DC551EA2 & Effluent & Healed & NG & None detected \\
\hline DD451EA2 & Effluent & Healed & NG & None detected \\
\hline DM231EB2 & Effluent & Healed & NG & None detected \\
\hline DM231EBON & Effluent & Healed & NG & $\begin{array}{l}\text { Acinetobacter sp. } 6013150 \\
\text { Acinetobacter baumannii plasmid ACICU } \\
\text { Acinetobacter baumannii plasmid pAB0057 } \\
\text { Acinetobacter baumannii AB0057 } \\
\text { Acinetobacter baumannii plasmid pMMA2 } \\
\text { Acinetobacter baumannii ATCC } 17978 \text { plasmid pAB2 } \\
\text { Salmonella enterica }\end{array}$ \\
\hline ET662EB2 & Effluent & Dehisced & NG & None detected \\
\hline ET662EBON & Effluent & Dehisced & NG & None detected \\
\hline HP561EA2 & Effluent & Healed & NG & HHV 6A \\
\hline HP561EB2 & Effluent & Healed & NG & HHV 6A \\
\hline HP561EBON & Effluent & Healed & NG & $\begin{array}{l}\text { HHV 6A } \\
\text { Pseudomonas sp. S-47 plasmid p47S* }\end{array}$ \\
\hline IS711EA2 & Effluent & Dehisced & NG & None detected \\
\hline IS711EB2 & Effluent & Dehisced & Stenotrophomonas maltophilia & None detected \\
\hline IS711EBON & Effluent & Dehisced & Stenotrophomonas maltophilia & $\begin{array}{l}\text { Pseudomonas aeruginosa PAb1 } \\
\text { Pseudomonas aeruginosa C3719 } \\
\text { Pseudomonas aeruginosa PAO1 } \\
\text { Pseudomonas aeruginosa UCBPP-PA14 } \\
\text { Pseudomonas aeruginosa PACS2 } \\
\text { Bordetella avium 197N } \\
\text { Achromobacter xylosoxidans A8 } \\
\text { Acinetobacter baumannii AB0057 plasmid pAB0057* } \\
\text { Klebsiella pneumoniae MGH78578* }\end{array}$ \\
\hline IS712EA2 & Effluent & Dehisced & NG & None detected \\
\hline IS712EB2 & Effluent & Dehisced & NG & None detected \\
\hline IS712EBON & Effluent & Dehisced & NG & $\begin{array}{l}\text { Acinetobacter sp. } 6013113 \\
\text { Acinetobacter baumannii plasmid pRAY } \\
\text { Acinetobacter baumannii SDF } \\
\text { Acinetobacter baumannii plasmid pMMA2 } \\
\text { Pseudomonas aeruginosa PAb1 } \\
\text { Pseudomonas aeruginosa C3719 } \\
\text { Pseudomonas aeruginosa PAO1 }\end{array}$ \\
\hline JC272EA2 & Effluent & Healed & Enterococcus faecium & None detected \\
\hline JD681EA2 & Effluent & Dehisced & NG & None detected \\
\hline JD682EA2 & Effluent & Healed & NG & HPV57* \\
\hline JG351EA2 & Effluent & Dehisced & $\begin{array}{l}\text { Bacillus cereus } \\
\text { Acinetobacter sp. }\end{array}$ & $\begin{array}{l}\text { Bacillus cereus AH676 } \\
\text { Pseudomonas stutzeri DSM4166* }\end{array}$ \\
\hline
\end{tabular}




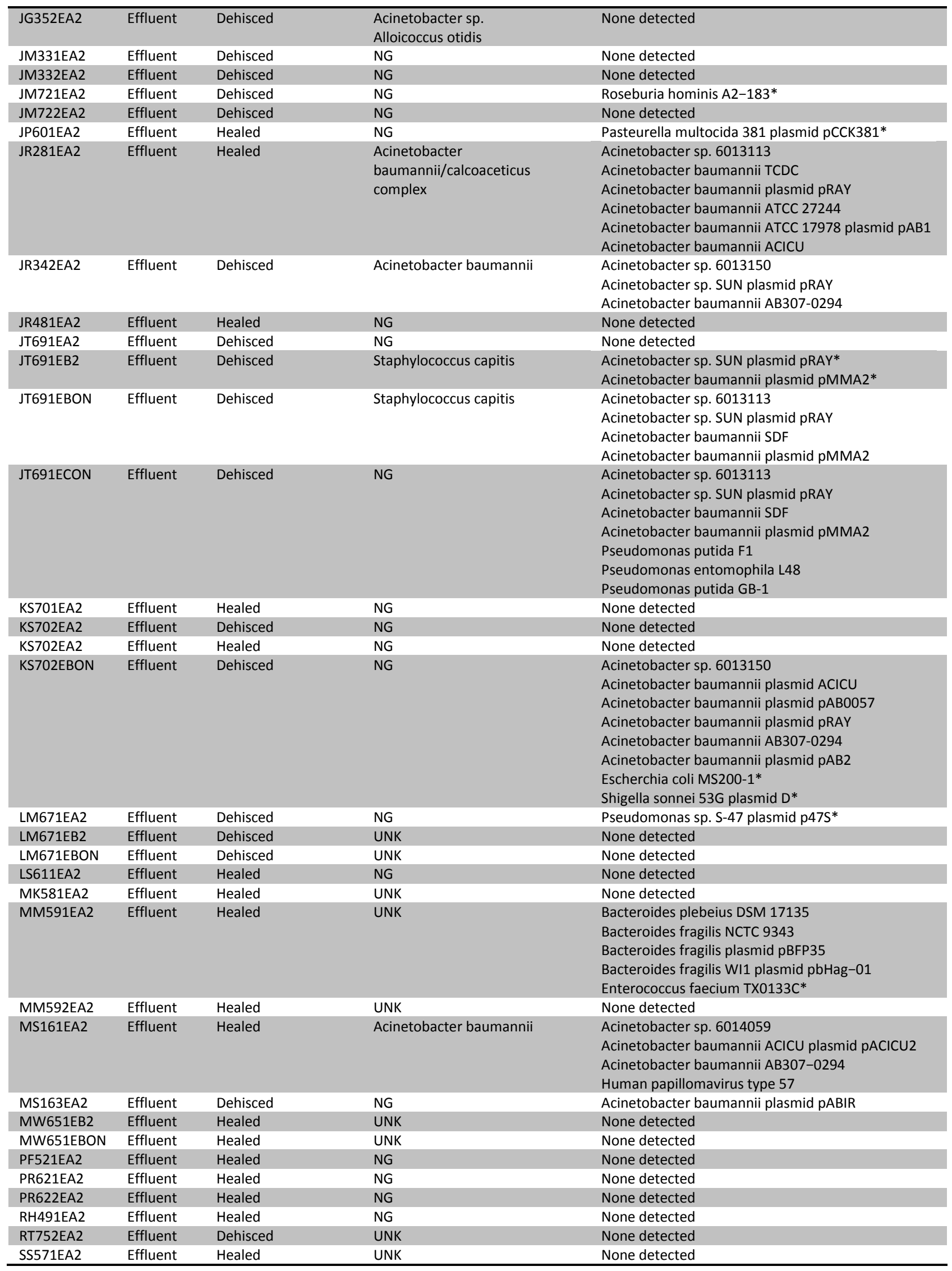




\begin{tabular}{|c|c|c|c|c|}
\hline TC541EA2 & Effluent & Dehisced & NG & None detected \\
\hline TC542EA2 & Effluent & Healed & NG & None detected \\
\hline TN631EA2 & Effluent & Healed & NG & None detected \\
\hline TN631EB2 & Effluent & Healed & Enterococcus faecium & *Streptomyces sp. x3 plasmid pTSC2 \\
\hline TN631EBON & Effluent & Healed & Enterococcus faecium & $\begin{array}{l}\text { *Streptomyces avermitilis } \\
{ }^{*} \text { Streptomyces sp. x3 plasmid pTSC2 }\end{array}$ \\
\hline ZB191EB2 & Effluent & Healed & $\begin{array}{l}\text { Enterobacter cloacae } \\
\text { Acinetobacter baumannii }\end{array}$ & $\begin{array}{l}\text { Acinetobacter sp. } 6014059 \\
\text { Acinetobacter baumannii ACICU } \\
\text { Acinetobacter baumannii AB307-0294 } \\
\text { Uncultured bacterium plasmid pB10 }\end{array}$ \\
\hline ZB191EBON & Effluent & Healed & $\begin{array}{l}\text { Enterobacter cloacae } \\
\text { Acinetobacter baumannii }\end{array}$ & $\begin{array}{l}\text { Acinetobacter sp. } 6014059 \\
\text { Acinetobacter baumannii ACICU plasmid pACICU } \\
\text { Acinetobacter baumannii AB307-0294 } \\
\text { Escherichia coli APEC O1 plasmid pAPEC-O1-R } \\
\text { Enterobacter sp. W001 plasmi pR23 } \\
\text { Uncultured bacterium plasmid pB10 }\end{array}$ \\
\hline
\end{tabular}




\section{APPENDIX B.}

Hierarchical charts demonstrating bacterial species detected by analysis of metagenomic sequence data from four additional samples in pilot sequencing run.

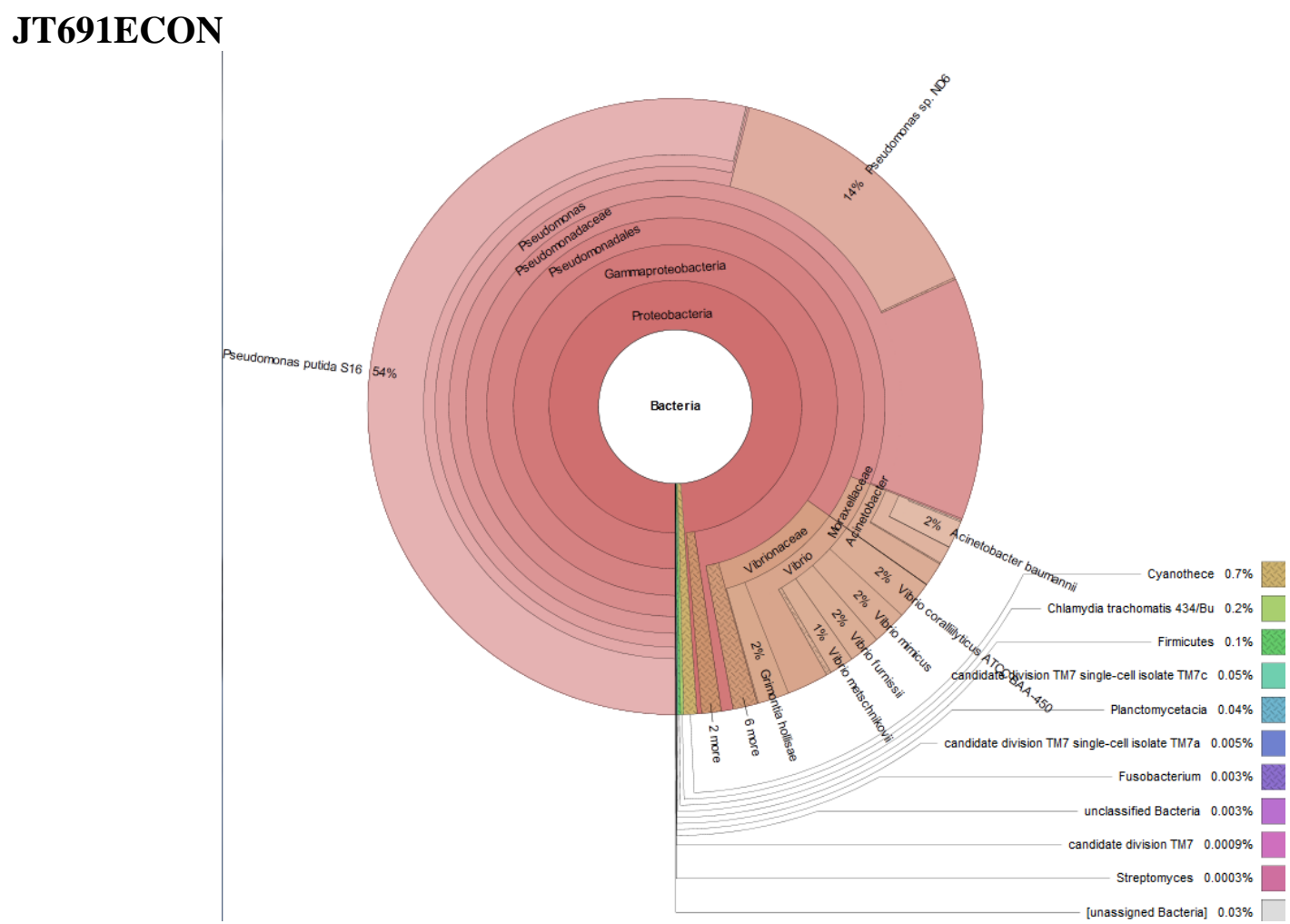

IS712WA

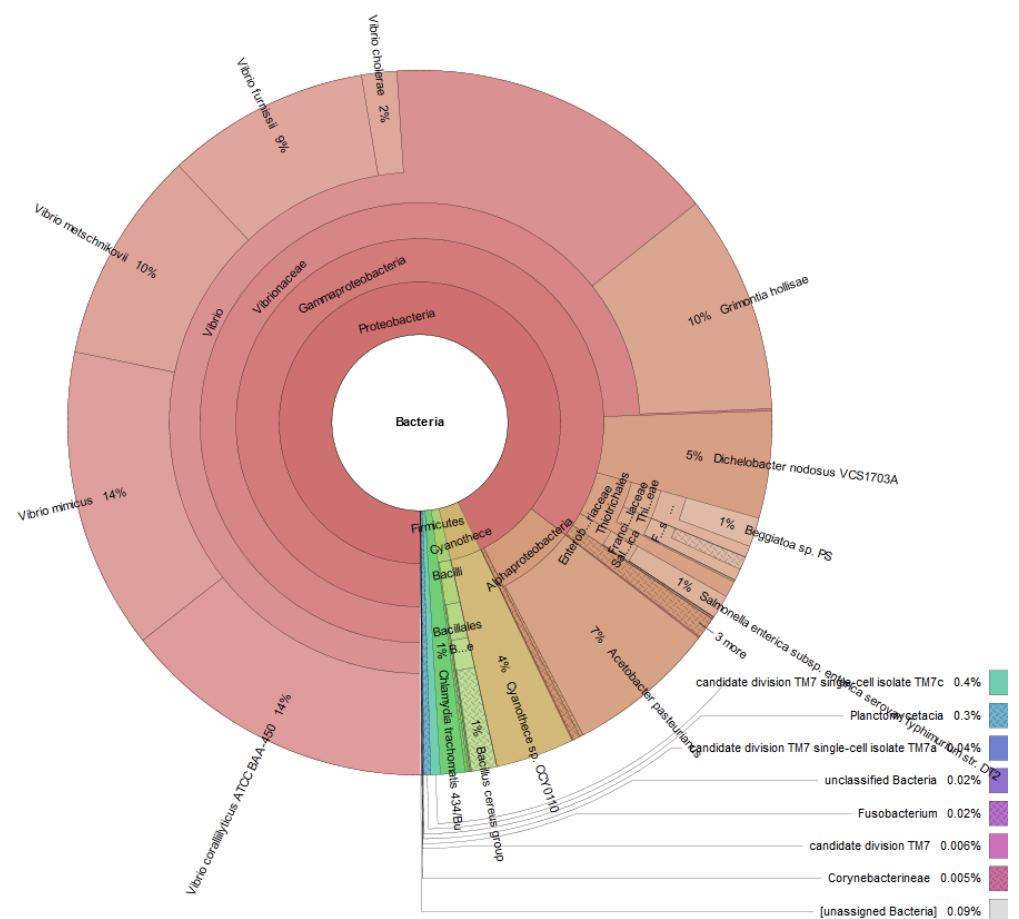




\section{JG352EA2}

\section{TN631WB}
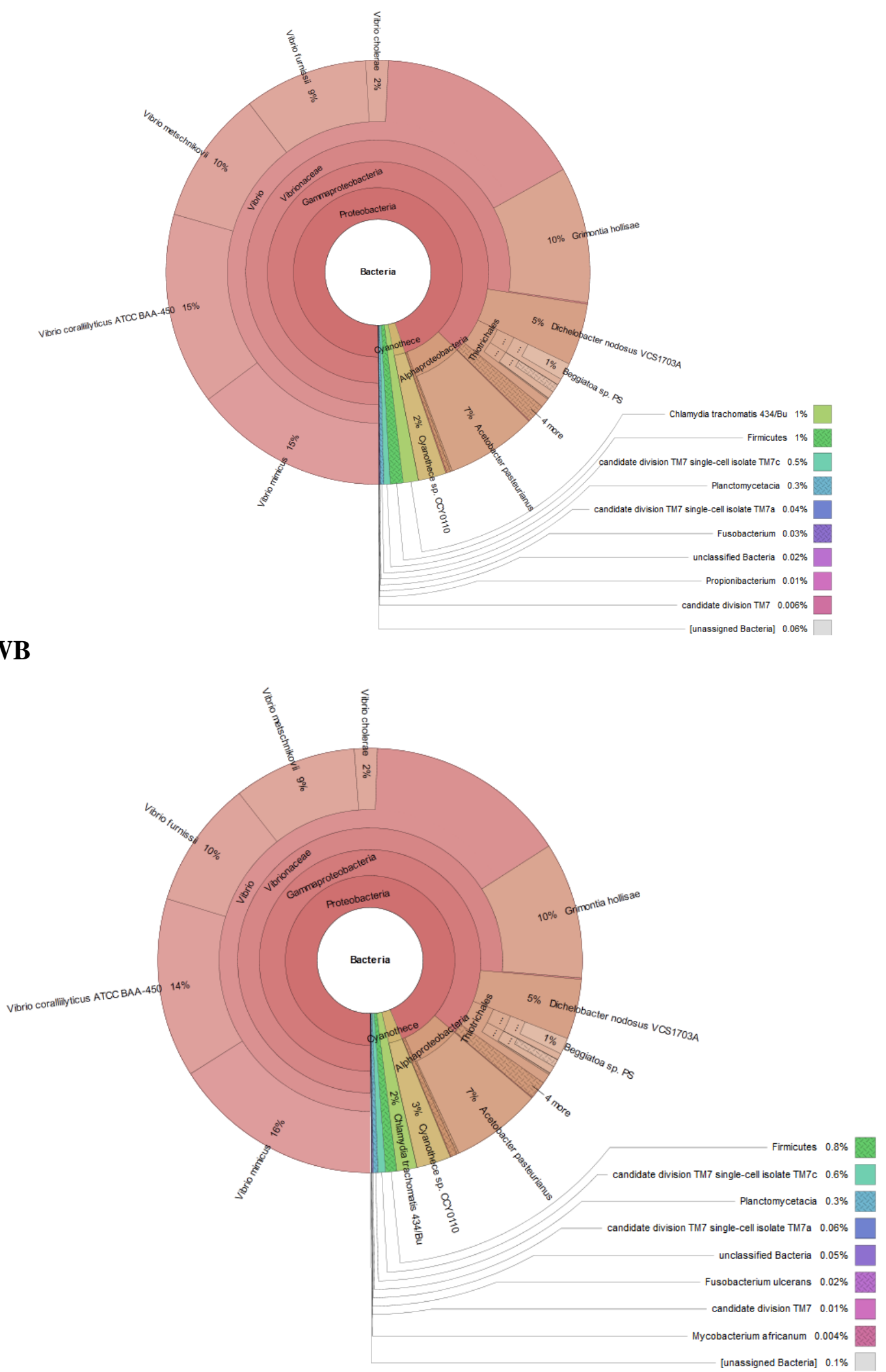